\title{
Teaching Information Literacy: Combating Fake News Through Library-Faculty Collaboration
}

\author{
Megan Benson \\ Binghamton University
}

Abstract: This column proposes a new approach to teaching information literacy in which librarians

work with faculty members to find examples of "fake news" in their discipline. This is an efficient method for teaching information literacy and creates stronger professional relationships between faculty and liaison librarians.

Author Bio: Megan Benson joined the Binghamton University Libraries in 2018 after completing her MLIS degree at Syracuse University. She also has a master's in history from the University of Nebraska Lincoln, where she focused on the perceptions of medieval women during the Early Modern Era. Megan previously taught at Valencia College in Orlando, FL., and has published entries in A Biographical Encyclopedia of Early Modern Englishwomen: Exemplary Lives and Memorable Acts, 1500-1650.

Keywords: information literacy, fake news, instruction

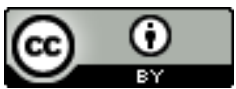

This is an Open Access article distributed under the terms of the Creative Commons Attribution 4.0 International License (http://creativecommons.org/licenses/by/4.0), which permits unrestricted use, distribution, and reproduction in any medium, provided the original work is properly cited. 
"Fake news" has seemingly been on the minds of every librarian for the last few years. While the term may be new, the actual practice of spreading false information and propaganda is not. It has always been important for students to analyze sources critically for their trustworthiness. In 2016 the Stanford History Education Group at the Stanford School of Graduate Education found that a majority of students lack this skill, particularly when examining online resources (Donald, 2016). Librarians often teach students to detect fake news, which is a skill transferable to all disciplines. With this in mind, I propose that liaison librarians work with faculty members to make information literacy a classroom priority by using discipline-specific examples. By doing so, an information literacy session does not take class time away from the subject, but in fact, relates to and re-enforces the course content. The approach can also be used to discuss scholarly communication, particularly in an upper-level class. I found this method useful during the spring semester of 2018.

That semester was my sixth year teaching and my last semester of library school. As an emerging librarian, I understood the importance of adding an information literacy lesson to my syllabus. As is often the case, however, I found it difficult to fit one in. Already a few weeks into the semester, I scoured my syllabus and added a lesson entitled, "Perkin Warbeck the Pretender and 'Fake News'" to my Late Middles Ages unit. Warbeck pretended to be Richard, the Duke of York-one of the "Princes in the Tower" in the 1490s. Warbeck was not the first to pretend to be one of these princes, but he was the most successful, convincing several European royals to support his cause. Ultimately, Warbeck was hanged for his crimes on November 23, 1497. Warbeck's use of propaganda and false information to commit his crime, makes him a prime example of fake news before the 21st century. My students discussed why Warbeck was able to convince European royalty that he too was royal, and they began to understand that fake news is not a new phenomenon. I then provided IFLA's 
"How to Spot Fake News" infographic (International Federation of Library Associations and Institutions, 2018), as well as a graded information literacy module created by our campus library. This module was a combination of lessons and quizzes and embedded into our learning module system. Students overwhelmingly passed the quizzes.

While students scored well on these quizzes, they unfortunately they did not really understand the concept, which I discovered when I asked one of the classes to find and share a scholarly source explaining why Anne Boleyn was killed. Of the 25 students in the class, only two shared scholarly sources, and only one used an article they found in the library catalog. Nearly all of the sources used were websites of varying veracity and most were from hobby historians. When I asked why the students chose their sources, they responded that they were reliable because the authors were interested in the topic. These results demonstrated that the previous lesson had not worked as well as hoped, despite the high marks on the quizzes.

Upon reflection and with the new perspective of a full-time librarian, I would adjust the lesson plan. For example, I would include more information to emphasize what makes a source "scholarly," and more visual resources, such as a screencast, to demonstrate how to navigate our library's website to find scholarly sources. Increased use of visual materials and a screencast would address visual learners' needs while also providing them a tutorial, which is often used in face-to-face library sessions. Although I had previously asked my students to share a scholarly article as a means of assessing the effectiveness of my previous lessons, in the future I would include follow up discussion and assignments if they continued to select popular articles.

While I was disappointed by my first attempts at teaching information literacy in a content class, I believe there are opportunities for this academic partnership to thrive. Librarians can work with 
faculty members to find examples of fake news, propaganda, etc., in the professor's discipline to reinforce the idea that misinformation is not a new phenomenon, demonstrating that it impacts all subjects. Meeting the professor for coffee allows them to share their expertise in an informal setting, which will also benefit the faculty and librarian's relationship overall, especially if the librarian is new to the profession and/or institution. ${ }^{1}$ Approaching information literacy from the lens of the class' subject content provides another avenue through which students' information literacy skills are reinforced by demonstrating their real-life implications. Fake news is not limited to one discipline nor to one mode of communication. This approach is different from a more traditional library instruction approach of sharing what the library has to offer and spins it to be more inclusive of the faculty's subject area, which might make faculty members more receptive to including a library session. Students will also be more invested in the lesson if the examples used are applicable to the course content. For this reason, I encourage using assignments that demonstrate what students have learned in the hosting professor's course.

To my knowledge, I have not seen an information literacy lesson approached in this manner. As David Gooblar argues in "How to Teach Information Literacy in an Era of Lies," "whatever your discipline, you should be teaching information literacy the capacity to understand, assess, evaluate, and apply information to solve problems or answer questions as part of your course" (Gooblar, 2018). Gooblar concludes by saying, "I'd argue that information literacy is one of those meta-skills that lurk behind the ability to master any subject. How can students succeed in any intellectual pursuit if they cannot tell what's true from what's false?" (Gooblar, 2018). Along these same lines, creating lessons

\footnotetext{
${ }^{1}$ Immediate examples that come to mind are yellow journalism and the idea that the measles, mumps, rubella (MMR) vaccine caused autism (Sathyanarayana, 2011).
} 
that incorporate information literacy into the subject matter is an effective solution. It reiterates the importance of information literacy and can be included in many disciplines without taking away class time. Drawing upon the experience and research of both faculty and librarians into information literacy lessons, we can ensure that students are taught these vital skills.

\section{References}

Donald, B. (2016, November 22). Stanford researchers find students have trouble judging the credibility of information online. Stanford University School of Education. Retrieved from https://ed.stanford.edu/news/stanford-researchers-find-students-have-trouble-judgingcredibility-information-online

Gooblar, D. (2018, July 24). How to teach information literacy in an era of lies. The Chronicle of Higher Education. Retrieved from https://www.chronicle.com/article/How-to-Teach$\underline{\text { Information } / 243973}$

International Federation of Library Associations and Institutions. (2018, July 17). How to spot fake news. Retrieved from https://www.ifla.org/publications/node/11174

Rao, T. S. Sathyanarayana, \& Andrade, C. (2011). The MMR vaccine and autism: Sensation, refutation, retraction, and fraud. Indian Journal of Psychiatry, 53(2), 95-96. Retrieved from https://www.ncbi.nlm.nih.gov/pmc/articles/PMC3136032

Wayland-Smith, E. (2017, February 26). Commentary: Where do students learn about fake news? In freshman comp. The Chronicle of Higher Education. Retrieved from https://www.chronicle.com/article/Commentary-Where-Do-Students/239266 